\title{
ARTYKUŁY
}

Klio. Czasopismo poświęcone dziejom Polski i powszechnym PL ISSN 1643-8191, t. 27 (4)/2013, s. 33-57

(c) $(1)$

DOI: http://dx.doi.org/10.12775/KLIO.2013.050

Richard Price

(Spalding)

\section{„Bardzo szczęśliwy obrót spraw”. Pokój w Ryswick a elekcja 1697 roku w Polsce}

Kiedy Gilbert Burnet, biskup Salisbury, pod koniec XVII wieku dodaIwał do swojego opisu historii Anglii kilka szczegółów dotyczących Polski, uznał, że powinien wytłumaczyć się z tego wtrętu. Przyznał, że Polska „leży bardzo daleko od nas”, ale to, co wydarzyło się tam w 1697 roku, miało wielki wpływ na sytuację w innych częściach Europy. Trwała wówczas wojna dziewięcioletnia (1688-1697), w której po jednej stronie znajdował się król Francji Ludwik XIV, a po drugiej król Anglii Wilhelm III i jego sojusznicy. Burnet wyjaśnit, że wydarzenia w Polsce przyczyniły się, dzięki „skłonieniu Francuzów do zawarcia pokoju”, do podpisania porozumienia, które zakończyło wspomnianą wojnę ${ }^{1}$.

Na początku ostatniej dekady XVII wieku informacje o wydarzeniach w Polsce rzadko przyciągały uwagę mieszkańców Anglii. Gazety z tego okresu zawierały niewiele wzmianek o Polsce, szczególnie na tle setek spraw, o których informowały każdego roku². Wzmianki były krótkie i zazwyczaj

1 G. Burnet, History of His Own Times, Oxford 1823, Vol. 4, s. 353.

2 Narcissus Luttrell, który w latach 1691-1695 pełnił funkcję posła do parlamentu 
ograniczały się do komunikatów o ruchach wojsk i działaniach militarnych, takich jak próby odbicia Kamieńca na pograniczu z imperium otomańskim. Okazjonalnie wspominano o posiedzeniach sejmu, ale nigdy nie wymieniono żadnej osoby, z wyjątkiem króla i dwójki jego dzieci, które zawarły związki małżeńskie w tych latach. Króla nie wymieniano z nazwiska, ale nie było takiej potrzeby. Anglicy dobrze znali postać Jana III Sobieskiego, a kiedy umarł w czerwcu 1696 roku, wspominali go jako „dzielnego władcę, który ocalił Wiedeń, a nawet całą Europę przed Turkami”’3.

Wiadomość o śmierci Sobieskiego opublikowano w „London Gazette” trzy tygodnie po tym fakcie ${ }^{4}$. W Anglii powszechnie sądzono, że tron po nim obejmie jego najstarszy syn. Kolejne informacje zamieszczane w „London Gazette” potwierdzały ten pogląd, zapewniając, że istnieje „bardzo nikły sprzeciw” wobec pretensji „księcia Jakuba”. Sobieski zrobił wszystko, co mógł, aby ustanowić w Polsce nową dynastię. Jego dzieci nosiły tytuły książęce, jego rodzinę przedstawiano jako rodzinę królewską, a to dzięki małżeństwom z dynastiami panującymi w innych państwach. Siostra księcia Jakuba została żoną elektora Bawarii, a w 1691 roku Jakub ożenił się z Jadwigą Elżbietą von Pfalz-Neuburg, szwagierką cesarza Leopolda I. W chwili śmierci swojego ojca książę Jakub miał prawie 30 lat, ale czytelnicy „Gazette” wiedzieli o nim bardzo mało. Nic z tego, co pisano na łamach "Gazette”, nie wskazywało, aby w rodzinie Sobieskich istniały spory, które mogłyby osłabić jego pozycję̧ ${ }^{6}$ Polska nie miała jednak króla, ale bezkrólewie i nie było wiadomo, kiedy ten stan się skończy. Podczas interregnum władza królewska przeszła w ręce arcybiskupa gnieźnieńskiego, kardynała-

angielskiego, zgromadził kilkadziesiąt tysięcy informacji z gazet ukazujących się między rokiem 1690 a 1694 . Tylko mniej niż 50 informacji dotyczyło spraw Polski.

3 The Diary of John Evelyn, ed. by E. S. de Beer, London 1959, s. 1009.

4 „London Gazette” [dalej: „Gazette”] była oficjalną gazetą ukazującą się w każdy poniedziałek i czwartek pod nadzorem podsekretarza stanu. W półtorarocznym okresie od śmierci Sobieskiego wyszły numery od 3191 do 3344 . Ze względu na to, że w Anglii do 1752 r. obowiązywał kalendarz juliański, w przypisach podaje się numer gazety, nie datę jej wydania. Wszystkie daty w artykule podane są według kalendarza gregoriańskiego.

5 Na przykład „London Gazette” 3203.

${ }^{6}$ Oczywiście między księciem a jego matką dochodziło do sporów o władzę i w kwestiach finansowych. 
-prymasa, co wynikało z braku automatycznej sukcesji tronu. Bez względu na to, czy posiadał roszczenia o charakterze dziedzicznym, czy też nie, następny władca musiał być wybrany.

Koniec XVII wieku jest często widziany jako czas triumfu monarchii dziedzicznej, czego najlepszym przykładem ma być panowanie Ludwika XIV. Jednak podobnie jak w Polsce, w wielu państwach monarchia miała charakter elekcyjny. Książęta-biskupi w Niemczech byli wybierani przez kapituły katedralne, papież był wybierany przez kardynałów, a cesarz nosił koronę przyznaną mu przez władców, którzy stosownie do tego określali się jako „elektorzy”. W ten sposób wyznaczano głowy państw w Wenecji, Genui i na Malcie. Bliżej Polski dziedziczny charakter miały trony w Czechach, na Węgrzech, w Danii i Szwecji. Od stuleci dziedziczni władcy próbowali sięgnąć po trony elekcyjne. Nietrudno zrozumieć, jak mogło do tego dojść: jeśli król okazał się dobrym monarchą, a jego syn wykazywał się odpowiednimi zdolnościami, to po co szukać dalej następcy? Sejmy i stany, które miały prawo wyboru władcy, mogły zatem akceptować sukcesję dziedziczną przez dwa, trzy pokolenia, ale zachowywały prawo wyboru każdego, kogo uznały za właściwego, gdy dana dynastia nie miała już odpowiedniego kandydata.

Dla panującego domu główne zadanie polegało na tym, aby mieć odpowiedniego kandydata we właściwym momencie i, jeśli było to możliwe, przekonać elektorów, aby potwierdzili jego prawo do tronu, zanim doszło do wakansu. Wyjątkowo biegli w tej sztuce okazali się Habsburgowie austriaccy. Głową rodziny był monarcha elekcyjny jako cesarz i król Węgier. Każdy cesarz zabiegał o uznanie najstarszego syna za swego następcę („król rzymski”) i z reguły przekazywał mu koronę węgierską na długo przed końcem swego panowania. Cesarz Leopold nie zwlekał, aby osiągnąć te cele. Przekazał koronę węgierską swojemu synowi Józefowi w 1687 roku, kiedy miał on zaledwie dziewięć lat, a trzy lata później skorzystał ze sposobności, aby przeprowadzić jego „szybką i łatwą elekcję” na króla rzymskiego ${ }^{8}$.

7 W Szwecji, która zdaniem Burneta była monarchią dziedziczną, w XVIII wieku trzykrotnie dokonano wyboru władcy.

${ }^{8}$ J. W. Stoye, The Austrian Habsburgs, [w:] The New Cambridge Modern History, Vol. 6, ed. by J. S. Bromley, Cambridge 1970, s. 586. 
Na początku ostatniej dekady XVII wieku podobnych wyborów dokonywano co kilka miesięcy, jak Europa długa i szeroka. W 1690 roku wybrano nowego wielkiego mistrza na Malcie, w 1694 roku nowego dożę w Wenecji. W Genui dożowie obejmowali urząd regularnie co dwa lata. W 1691 roku dokonano wyboru nowego papieża. Papież Aleksander VIII zmarł w lutym, a jego następca, Innocenty XII, zajął miejsce w lipcu. W tym wypadku doszło do długiego interregnum - podobnie będzie w Polsce sześć lat później. W ostatecznym głosowaniu wzięło udział 60 kardynałów „zamkniętych” na konklawe przez ponad 100 dni. Podobnie jak w Polsce, wśród głosujących aktywna i wpływowa była fakcja francuska. W czerwcu pojawiły się informacje, że „francuskie galery pojawiły się u wybrzeży Civitavecchia z zamiarem... zastraszenia kardynałów, aby wybrali papieża odpowiadającego Francji”" .

Najczęściej elekcje przeprowadzano w Niemczech, tam gdzie biskupi i arcybiskupi byli również władcami świeckimi. W Moguncji, gdzie arcybiskup był jednym z elektorów cesarstwa, kapituła katedralna głosowała trzy razy w ciagu czterech lat. W 1691 i 1694 roku wybrano koadiutora, aby pomagał aktualnemu arcybiskupowi i, według wszelkiego prawdopodobieństwa, go zastąpił. Pierwszy koadiutor zmarł przedwcześnie ${ }^{10}$, ale następny, Lothar Franz von Schönborn, został arcybiskupem po kolejnym głosowaniu, które odbyło się w 1695 roku. Schönborn zajmował stanowisko arcybiskupa Moguncji przez trzy dekady, ale zazwyczaj książęta-biskupi rządzili krócej niż świeccy władcy dziedziczni. W Bambergu nowych biskupów wybierano co 15 lat $^{11}$, rządy papieży trwały jeszcze krócej. Czytelnicy w Anglii byli zatem przyzwyczajeni do informacji o monarchiach elekcyj-

9 N. Luttrell, A Brief Historical Relation of State Affairs from September 1678 to April 1714, Vol. 2, Oxford 1857, s. 231, 246, 269.

${ }^{10}$ Ludwik Antoni von Pfalz-Neuburg (1660-1694), o którym będzie jeszcze mowa.

11 Według Catholic Encyclopedia (pol. Encyklopedia katolicka) między pokojem westfalskim a sekularyzacją w 1807 r. wyboru biskupa w Bambergu dokonywano co 15 lat. W ciągu 800 lat (1007-1802) wybrano 63 biskupów, średnio każdy sprawował urząd mniej niż 13 lat. Przykładowo, Habsburgowie austriaccy zasiadali na tronie średnio znacznie dłużej. Między rokiem 1440 a 1740 tylko 12 Habsburgów zasiadało na tronie cesarskim, co oznacza, że średnio na każde stulecie przypadało tylko czterech spośród nich. 
nych i fakt, że nowy władca Polski obejmie tron dzięki elekcji, nie wydawał się niczym zaskakującym czy niezwykłym.

Największe zainteresowanie wśród wszystkich elekcji na początku ostatniej dekady XVII wieku wzbudziła ta w Liege. Po wywalczeniu na początku stulecia niepodległości przez Holendrów, władcy Hiszpanii zachowali posiadłości w południowej części Niderlandów, w skład których wchodziła Bruksela. Posiadłości hiszpańskie były przedzielone na dwie części przez małe i autonomiczne państewko, biskupstwo Liege. Nie dość, że biskupstwo dzieliło posiadłości hiszpańskie, to jeszcze tworzyło korytarz o długości około 100 mil, rozciągający się od granicy ze Zjednoczonymi Prowincjami na północy do granicy francuskiej na południu. Nic więc dziwnego, że o przyjaźń, a przynajmniej o życzliwą neutralność księcia-biskupa Liege zabiegali Francuzi, Holendrzy i Hiszpanie. Podczas wyborów nowego biskupa w 1694 roku poszczególni kandydaci zyskali poparcie obcych państw. Kardynał Emmanuel de Bouillon był ważnym członkiem dworu Ludwika XIV, Józef Klemens Wittelsbach, który miał już tytuł arcybiskupa i elektora Kolonii, był bratem elektora Bawarii, a Ludwik Antoni (wielki mistrz zakonu krzyżackiego) był członkiem domu Pfalz-Neuburg i szwagrem cesarza Leopolda.

Kilka tygodni przed wyborami Francuzi zagrozili interwencją zbrojną na rzecz kardynała de Bouillon, podobnie jak podczas wyboru papieża trzy lata wcześniej. Nie przyniosło to spodziewanego efektu i Francuzi udzielili poparcia elektorowi Kolonii, który z trudem wygrał pierwsze głosowanie w piątek 20 kwietnia. Dziekan kapitulny Liege, opisywany przez współczesnych sobie jako „nieubłagany wróg Francji” ${ }^{12}$, połączył swoje siły z siłami wielkiego mistrza i zwołał zebranie kapituły na następny dzień. Stwierdził, że podczas pierwszego głosowania doszło do nieprawidłowości i wezwał członków kapituły do ponownego oddania głosów. Tym razem zwycięzcą ogłoszono wielkiego mistrza. Sytuacja bardzo przypominała tę, która miała miejsce trzy lata później w Polsce, kiedy początkowo przewagę zdobył najsilniejszy kandydat, ale szybko został pokonany przez przeciwników, którzy połączyli swoje siły. W Polsce taka taktyka przyniosła pożądane efekty, ale

12 N. Luttrell, op. cit., Vol. 3, s. 285. 
w Liege było inaczej. W ciągu dwóch tygodni od podwójnej elekcji pojawiły się wiadomości, że doszło do gwałtownego wybuchu choroby, która pochłonęła setki ludzi ${ }^{13}$. Jedną z ofiar był wielki mistrz. W takiej sytuacji zwycięzcą okazał się elektor Kolonii.

Wybór nowego księcia-biskupa Liege nie miał wiele wspólnego z religią. W gruncie rzeczy było to przedłużenie wojny między wielkimi mocarstwami, a kandydaci do stanowiska byli ich przedstawicielami. Każdy konflikt tego typu dawał Ludwikowi XIV okazję do poszerzenia strefy wpływów. Z kolei dla Wilhelma III i jego sojuszników była to szansa na powstrzymanie ekspansji francuskiej, a nawet na odzyskanie utraconych wpływów. Wojna dziewięcioletnia, w większym stopniu niż inne konflikty, przypominała skomplikowaną partię szachów ${ }^{14}$. Stolica biskupia w Liege była wolnym polem na szachownicy i każda ze stron konfliktu próbowała umieścić na nim biskupa. Kiedy pole o nazwie Polska stało się wolne, Ludwik XIV i jego przeciwnicy próbowali je zająć, ale tym razem za pomocą pionka chcieli zdobyć koronę ${ }^{15}$. Francuskim pionkiem był François Louis de Burbon, książę de Conti.

Francja miała silne wpływy w Polsce. W Warszawie rezydował ambasador francuski, a królowa wdowa była córką francuskiego szlachcica. W listopadzie 1696 roku w „London Gazette” pojawiły się informacje, że ambasador francuski przekonał królową wdowę, aby wysłała swych młodszych synów, Aleksandra i Konstantego, do Francji, aby trzymać ich z dala od kłopotów. Krążyły także pogłoski, że królowa, nie mogąc wpłynąć na księcia Jakuba, zdecydowała się popierać pretensje jego brata Aleksandra, który miał mniej doświadczenia i z tego powodu był bardziej uległy ${ }^{16}$. Obydwaj książęta pozostali we Francji dłużej, niż pierwotnie zakładano. Nie ma wątpliwości, że Ludwik XIV skorzystał ze sposobności, aby zmniejszyć liczbę pionków.

13 Ibidem, s. 305.

14 Kampania w Niderlandach dobrze ilustruje takie porównanie. Nie było jednej linii frontu, a figury (armie) poruszały się ze względną swobodą wokół umocnionych pozycji przypominających królów.

15 Trzy niemieckie pionki (elektorzy Saksonii, Brandenburgii i Hanoweru) sięgnęły po korony między rokiem 1697 a 1714.

16 „Gazette” 3242. Aleksander i Konstanty nosili imiona, które w porównaniu z ich starszym bratem Jakubem wskazywały na większe ambicje. 
Natychmiast po śmierci Jana III Sobieskiego zakładano, że „Francja odegra aktywną rolę, tak jak podczas wszystkich poprzednich elekcji” ${ }^{17}$. Wkrótce w „Gazette” pojawiły się informacje o francuskich pieniądzach napływających do Polski, dzięki którym ambasador miał kupić poparcie dla „swojego” kandydata. Ambasadorem był opat de Polignac, a w gazetach w Anglii powtarzano informacje o jego wysiłkach mających na celu stworzenie partii, która poparłaby Contiego. Aktywność ambasadora wywołała oburzenie w Polsce; doszło nawet do oficjalnego potępienia „działań i intryg", w których uczestniczy ${ }^{18}$.

Najpoważniejszym kandydatem do korony wydawał się Jakub Sobieski. Można przypuszczać, że gdyby do elekcji doszło w ciągu kilku tygodni po śmierci jego ojca, zostałby ogłoszony królem. W każdym razie do takiego wniosku przekonywano czytelników w Anglii, twierdząc na łamach „London Gazette”, że elekcja zostanie przeprowadzona w sierpniu 1696 roku. Jednak w kolejnych numerach wyjaśniono, że tak wczesna elekcja jest niemożliwa („,stało się zwyczajem, że nie przystępuje się do wyboru nowego króla aż dopiero w sześć miesięcy po śmierci poprzedniego"), aż wreszcie pojawiła się wiadomość, że elekcja została odłożona do wiosny 1697 roku $^{19}$.

W Anglii, w informacjach na temat bezkrólewia w Polsce, zaczęto wspominać też o innych postaciach. W „Gazette” pojawiły się odniesienia do królowej i prymasa, choć bez imion czy nazwisk ${ }^{20}$. Pojawiło się także kilka polskich rodzin - Sapiehów, Jabłonowskich i Lubomirskich - jednak nie podawano imion ich przedstawicieli. O innych ważnych postaciach wspominano tylko poprzez urzędy, które sprawowali, na przykład kasztelanowie czy biskupi ${ }^{21}$. Kolejne osoby przedstawiano w jeszcze mniej dokładny sposób jako „ważne postacie”. Nie było żadnych informacji na temat charakteru tych ludzi, bardzo rzadko też pisano o motywach ich postępowania.

17 „Gazette” 3197.

18 „Gazette” 3253.

19 "Gazette” 3200, 3208 i 3220.

20 Maria Kazimiera de La Grange d'Arquien i Michał Stefan Radziejowski.

21 Znalazło się wśród nich kilka odniesień do biskupa płockiego Andrzeja Chryzostoma Załuskiego, który ponad 10 lat później opublikował dokumenty związane z interregnum w dziele Epistolae historico-familiares. 
Pod koniec 1696 roku czytelników „London Gazette” zapewniano, że jest tylko dwóch poważnych kandydatów do tronu: Jakub Sobieski i książę Conti. Uwagę zaczęli przyciągać jednak nowi kandydaci. Najpoważniejszym wydawał się młody Leopold I Józef, książę lotaryński, którego matka, Eleonora Habsburżanka, była siostrą cesarza Leopolda oraz wdową po królu Michale Korybucie Wiśniowieckim. Mogło się wydawać, że w Niemczech istnieje silne poparcie dla tej kandydatury ${ }^{22}$, ale brak doświadczenia i ograniczone możliwości materialne przemawiały przeciwko księciu. W „Gazette” wspominano także o księciu neuburskim, Karolu Filipie (kolejny bliski krewny cesarza) i Livio Odeschalchim (bratanek papieża Innocentego XI) ${ }^{23}$, ale czytelnicy wkrótce zrozumieli, że najpoważniejszym kandydatem wśród tych, którzy pojawili się w ostatnim czasie, był książę Ludwik Wilhelm Badeński. Sześć lat wcześniej odznaczył się on jako dowódca armii cesarskiej na Węgrzech, odnosząc wielkie zwycięstwo nad Turkami w bitwie pod Slankamen. Od tego czasu służył cesarzowi jako jeden ze sprzymierzonych dowódców na zachodzie Europy. Dla tych, którzy opowiadali się za królem z doświadczeniem dowódcy, książę Ludwik był oczywistym wyborem. W kwietniu 1697 roku „Gazette” podała, że ponieważ książę wydaje się jedynym kandydatem zdolnym skutecznie przeciwstawić się księciu Conti, uzyska wsparcie ze strony cesarza ${ }^{24}$.

Gazety, w których omawiano szanse poszczególnych kandydatów, zawierały także krótkie informacje o innych wydarzeniach w Polsce w 1697 roku. Dotyczyły one między innymi wypłacenia należnych pieniędzy zbuntowanemu wojsku oraz zabiegów mających na celu pozbycie się z Warszawy wdowy po Janie III Sobieskim i w ten sposób ograniczenie jej wpływu na elekcję. Królowa opierała się najdłużej jak się dało, wreszcie w kwietniu opuściła Warszawę i wyruszyła na północ do Gdańska ${ }^{25}$. Pięć tygodni po jej wyjeździe bezkrólewie weszło w decydującą fazę. W środę 15 maja rozpoczynał się sejm.

\footnotetext{
22 N. Luttrell, op. cit., Vol. 4, s. 109.

23 "Gazette” 3271 i 3288.

24 "Gazette” 3278.

25 "Gazette” 3285 i 3286.
} 
Informacje na jego temat dotarły, jak zazwyczaj, z około trzytygodniowym opóźnieniem ${ }^{26}$. Wiele elementów związanych z obradami sejmu było dobrze znanych czytelnikom w Anglii, takich jak spory przy wyborze marszałka izby poselskiej czy rugi poselskie („dotyczyły tych posłów, wobec których pojawiły się oskarżenia, że nie wybrano ich we właściwy sposób”) ${ }^{27}$. Najważniejsza sprawa w okresie interregnum, o której wspominano w „Gazette” kilkukrotnie, dotyczyła prawa oddania głosu podczas elekcji. W czasie wcześniejszych wyborów ustanowiono kilka precedensów, dobrze rozumianych w Anglii, gdzie spory dotyczące prawa do głosowania często prowadziły do wyboru dwóch zestawów posłów. Można nawet stwierdzić, że cały proces elekcji i nakładania na jej zwycięzcę warunków, które musiał wypełnić, nawiązywały do wcześniejszych o osiem lat doświadczeń Anglików, choć wielu polityków angielskich z oburzeniem odrzucało taką interpretację sławetnej rewolucji z 1689 roku $^{28}$.

Kilka dni przed sejmem w Warszawie na zachodzie Europy prace rozpoczęło inne zgromadzenie. W Ryswick koło Hagi zaczął się kongres, który doprowadził do zakończenia wojny dziewięcioletniej. Każda ze stron konfliktu mogła pochwalić się kilkoma większymi sukcesami, a co roku, pod koniec każdej kampanii, pojawiały się nieoficjalne propozycje pokojowe. Wilhelm III i jego sojusznicy walczyli, aby powstrzymać rozwój potęgi Francji. Nie mieli nadziei na decydujące zwycięstwo, chcieli natomiast uniknąć klęski. Celem Ludwika XIV było utrzymanie zdobyczy terytorialnych, które poczynił na początku swojego panowania. W 1697 roku obydwie strony miały trudności ze znalezieniem ludzi i pieniędzy do dalszego prowadzenia wojny. Bardziej wyczerpana była Francja, dlatego niezobowiązujące oferty pokoju pochodziły głównie od niej.

${ }^{26}$ Między wydarzeniami w Polsce a publikacją wiadomości na ich temat w „Gazette” mijało zazwyczaj około 22 dni. Przykładami: śmierć Sobieskiego w czerwcu 1696 r., rozpoczęcie obrad sejmu w maju 1697 r. i koronacja elektora saskiego we wrześniu tego samego roku.

27 „Gazette” 3221.

${ }_{28} \mathrm{Na}$ temat głosów w parlamencie angielskim o Polsce, wakujących tronach i państwach elekcyjnych, zob.: D. L. Jones, A Parliamentary History of the Glorious Revolution, London 1988, s. 93, 111-112. 
Najbardziej efektywnym kanałem komunikacji okazały się tajne spotkania między francuskim dyplomatą François de Callières i holenderskim odpowiednikiem, Everardem van Weede van Dijkveltem. Rozmowy między nimi rozpoczęły się już w 1694 roku, ale aż do grudnia 1696 roku nie osiągnięto żadnego postępu. Wtedy to niespodziewanie Francuzi zgodzili się ograniczyć swoje wsparcie dla Jakuba II i uznać Wilhelma III za króla Anglii. Miesiąc później de Callières poczynił kolejne ustępstwo, godząc się, aby oficjalne rozmowy pokojowe prowadzono na terytorium Zjednoczonych Prowincji. Wyznaczono mediatora i ustalono wstępne warunki porozumienia. Obydwie strony wyznaczyły swych pełnomocników, w marcu 1697 roku przedstawiciele Ludwika XIV wyruszyli do Holandii. Ich angielscy odpowiednicy przybyli kilka tygodni późniejej. Pierwsza sesja odbyła się w czwartek 9 maja, zgodzono się, że negocjatorzy będą spotykali się w kolejne środy i soboty.

Jednak walki na frontach nie skończyły się wraz z rozpoczęciem rozmów pokojowych. Na początku roku de Callières ostrzegał, że jeśli warunki pokoju nie zostaną ustalone przed rozpoczęciem kolejnej kampanii, wojna będzie toczyła się dalej ${ }^{30}$. Szwedzki ambasador Nils Lillieroot, który pełnił funkcję mediatora, wyraził zaniepokojenie, że nie podpisano zawieszenia broni, które zapobiegłoby wznowieniu walk. Stwierdził, że negocjatorzy w Ryswick zwrócą uwagę na sytuację militarną i będą „podnoszeni na duchu bądź przygnębieni” w zależności od informacji z frontu ${ }^{31}$. Do podobnego wniosku doszli także inni obserwatorzy. Richard Hill ${ }^{32}$ twierdził, że sukcesy militarne Francuzów zapewnią im przewagę przy stole negocjacyjnym, a książę Shrewsbury ${ }^{33}$ obawiał się, że mogą skłonić ich do rezygnacji z rozmów pokojowych: „mogą uznać, że lepiej zdobywać kolejne miasta

29 Thomas Herbert, earl of Pembroke; Edward Villiers; Sir Joseph Williamson.

${ }^{30}$ N. Luttrell, op. cit., Vol. 4, s. 181.

31 A. Boyer, The History of King William the Third, London 1703, Vol. 3, s. 253.

32 Richard Hill był skarbnikiem armii oraz posłem nadzwyczajnym do gubernatora Niderlandów Hiszpańskich. Po śmierci Sobieskiego i pojawieniu się pogłosek, że Ludwik XIV może zabiegać o tron polski dla wygnanego króla Anglii Jakuba II, stwierdził złośliwie: „Nie znam nikogo, kto byłby przeciwny tej kandydaturze z wyjątkiem Polaków”.

33 Charles Talbot, książę Shrewsbury pełnił w latach 1695-1698 funkcję sekretarza stanu departamentu południowego. 
w trakcie wojny, niż oddawać je na mocy traktatu" ${ }^{34}$. Nie podpisano zawieszenia broni, a rezultat był dokładnie taki, jak przewidywano. Rozmowy pokojowe były ciągle opóźniane ze względu na obawy i nadzieje obydwu stron, w zależności od wiadomości napływających z frontu, a od lata 1697 roku także od wiadomości z Polski.

Przy tak wielu ostrzeżeniach Wilhelm III i jego sojusznicy nie byli zaskoczeni, że tydzień po rozpoczęciu negocjacji pokojowych w Ryswick Ludwik XIV rozpoczął kolejną ofensywę. Pierwszy cios spadł na Ath, garnizonowe miasto w Niderlandach południowych. Gubernator Ath, hrabia de Roeux, miał pod swoim dowództwem żołnierzy z różnych oddziałów, a miasto było silnie ufortyfikowane. Garnizon był jednak nieco słabszy, niż być powinien, a część oficerów była nieobecna w mieście w chwili rozpoczęcia oblężenia w czwartek 16 maja. Tego dnia gubernatorowi wręczono notę, w której stwierdzono, że „wszystkie kobiety znajdujące się w mieście mogą je bezpiecznie opuścić" ${ }^{35}$. Sojusznicy oceniali, że miasto utrzyma się 20 dni, ale Sebastian Vauban sądził, że zdobędzie je w ciągu 12 dni.

Oblężenie rozpoczęto w łatwy do przewidzenia sposób. Francuzi zbudowali okopy i rozpoczęli ostrzał artyleryjski. Dokonali kilku wyłomów w obronie i kiedy przygotowywali się do decydującego ataku, gubernator poprosił o pertraktacje. Garnizon skapitulował w środę 5 czerwca, czyli dwudziestego dnia oblężenia, a dwa dni później żołnierzom pozwolono opuścić miasto „z bronią, bagażami, przy dźwiękach bębnów i z powiewającymi sztandarami etc., ale bez armat" ${ }^{36}$. Mimo honorowych warunków kapitulacji nie wszyscy uważali, aby de Roeux i garnizon wykazali się odpowiednim duchem walki. Kilka lat później Abel Boyer podsumował oblężenie jako „bardzo energiczne po stronie francuskiej”, a obronę określił jako „bardzo słabą" ${ }^{37}$.

34 Historical Manuscripts Commission. Report on the Manuscripts of the Duke of Buccleuch and Queensberry, Vol. 2, London 1903, s. 473, 479.

35 N. Luttrell, op. cit., vol. 4, s. 226.

36 „Gazette” 3288, 3290-3392 i 3295; N. Luttrell, op. cit., Vol. 4, s. 236.

37 A. Boyer, op. cit., Vol. 3, s. 254. 
Jak zauważył Burnet, Francuzi, zachęceni sukcesem, „dokładali starań, aby odnieść jak najwięcej korzyści w trakcie kampanii”"38. Ich dwa kolejne cele miały dużo większe znaczenie. Tydzień po kapitulacji Ath siły francuskie zaatakowały Barcelonę. Co gorsza, w sobotę 22 czerwca Francuzi podeszli pod Brukselę i zagrozili zbombardowaniem miasta. Wilhelm III nie był w stanie zrobić nic w przypadku Katalonii, ale szybko zareagował na zagrożenie Brukseli. Dzięki nocnemu marszowi i zajęciu pozycji w Anderlechcie, na zachód od Brukseli, zatrzymano francuską ofensywę.

Dzięki sukcesom w polu Ludwikowi XIV nie spieszyło się do zawarcia pokoju. Matthew Prior, sekretarz angielskich pełnomocników w Ryswick, pisał pod koniec czerwca, że Francuzi czekali na rezultaty oblężenia Barcelony przed powrotem do negocjacji. Wkrótce potem stwierdzit, że Francuzi czekają także na wiadomości z Polski, mając nadzieję, że zwycięstwo kandydata francuskiego wzmocni ich pozycję podczas rozmów pokojowych ${ }^{39}$. Zanim jeszcze Prior napisał obydwa listy, elekcja w Polsce już się odbyła, ale informacje na ten temat w „London Gazette” jeszcze się nie pojawiły. Kiedy wreszcie to nastąpiło, wieści były bardzo obszerne. Wersja wydarzeń przedstawiona $\mathrm{w}$ „Gazette” była niepełna, a nawet nieścisła w niektórych punktach, ale niewątpliwie była logiczna, przekonująca i miała decydujące znaczenie dla sposobu, w jaki Anglicy postrzegali wydarzenia na drugim końcu Europy.

Na początku lipca 1697 roku w „Gazette” pojawiła się pierwsza informacja na temat nowego kandydata do tronu polskiego, 27-letniego elektora saskiego ${ }^{40}$. Wiadomość przyjęto ze zdziwieniem. Elektor był wyznania luterańskiego i w tym czasie dowodził wojskami cesarskimi na Węgrzech ${ }^{41}$. Wyglądało na to, że zmienił wyznanie i zrezygnował z dowództwa, aby stawić czoła księciu Conti. Jeszcze większym zaskoczeniem był fakt, że mu się udało. Burnet w następujący sposób podsumował opinię „Anglika” na temat tego, co się zdarzyło:

38 G. Burnet, op. cit., Vol. 4, s. 345.

39 Historical Manuscripts Commission. Calendar of the Manuscripts of the Marquis of Bath, Vol. 3, London 1908, s. 130, 134.

40 Fryderyk August I. „Gazette” 3302.

$41 \mathrm{~W}$ środę, 22 maja, podano wiadomość z Wiednia, że miał on wrócić do armii na terenie Węgier („Gazette” 3292). 
elektor zgłosił swoją kandydaturę zaledwie kilka dni przed elekcją, a... partia, która go popierała, bardzo szybko stała się tak silna, że mimo tego, iż na pierwszy rzut oka podczas elekcji najsilniejsza była francuska, co ogłosił kardynał, inni kandydaci widząc, że nie mogą liczyć na zwycięstwo, zjednoczyli się przeciwko kandydatowi francuskiemu i przekazali swoje głosy elektorowi saskiemu, dzięki czemu jego partia stała się najsilniejsza a jego samego ogłoszono królem² ${ }^{42}$.

Dniem wyznaczonym na elekcję była środa 26 czerwca, ale spór ciągnął się i następnego dnia. Cztery tygodnie później w „London Gazette” opublikowano wyjątkowo długą relację na ten temat ${ }^{43}$, która dała czytelnikom wyobrażenie co do sposobu elekcji. Najpierw oficjalnie przedstawiono imiona kandydatów, po czym wyborcy (licznie zgromadzona na otwartym polu szlachta „na koniach”) wyrażali poparcie dla nich według własnego uznania. Największą aprobatę zyskali Jakub Sobieski i książę Conti. Podczas następnego etapu elekcji „każda ze stron podejmowała starania, aby pokonać przeciwnika”. Jednak żadna nie mogła zwyciężyć i dlatego zaproponowano, aby wycofać te dwie kandydatury, a głosy oddać na rzecz innego kandydata. Zwolennicy Sobieskiego zgodzili się i głosowali na rzecz elektora saskiego, ale zwolennicy Contiego odrzucili propozycję. W rezultacie, pod koniec drugiego dnia, doprowadziło to do podwójnej elekcji. Prymas oficjalnie zaaprobował wybór księcia Conti, a innego hierarchę duchownego ${ }^{44}$ przekonano, aby ogłosił, że większość głosów zdobył elektor saski. Jak już zauważono, wydarzenia w Warszawie w dużym stopniu przypominały wypadki sprzed trzech lat w Liege.

W tej samej relacji zamieszczonej w „London Gazette” stwierdzono, że przed końcem tygodnia, w którym przeprowadzono elekcję, zwolennicy elektora podjęli bardziej efektywne działania niż ich przeciwnicy. W piątek „podpisali zwyczajowy dokument”, a w sobotę zebrali się ponownie, aby „przygotować umowę, którą ma podpisać nowy król”. W relacji pojawiła się też sugestia, że mieli więcej argumentów w utarczkach słownych, do których doszło po elekcji. Twierdzili, że elekcja została skonstruowana

${ }^{42}$ G. Burnet, op. cit., Vol. 4, s. 349-350.

43 „Gazette” 3306. Informacja była datowana na piątek 5 lipca i liczyła tysiąc wyrazów.

44 Stanisław Dąmbski, biskup kujawski. 
w taki sposób, aby poprzez negocjacje i jednomyślną zgodę doprowadzić do wyboru nowego króla ${ }^{45}$. Byli gotowi dostosować się do tego mechanizmu, natomiast ich przeciwnicy go negowali.

Pierwsze pogłoski na temat wyników elekcji dotarły do Europy Zachodniej dwa tygodnie po dokonaniu podwójnego wyboru. Sprzeczne wiadomości na ten temat krążyły w Paryżu i Hadze. W środę 10 lipca Matthew Prior zanotował: ,jedyną rzeczą, o której się tutaj rozmawia, jest wybór elektora saskiego na króla polskiego" ${ }^{46}$. Tego samego dnia, po nadejściu wiadomości o zwycięstwie księcia Conti, w Wersalu panowała „bardzo wielka radość" ${ }^{47}$. Dwa tygodnie później w Londynie Charles Talbot, książę Shrewsbury, ciągle był „niezbyt pewien”, w którą wersję uwierzyć. Informacje z Francji potwierdzały, że zwycięsko z elekcji wyszedł książę Conti, natomiast listy z Holandii stwierdzały, że sukces elektora saskiego był „niepodważalny" ${ }^{48}$.

W takiej sytuacji było jasne, że w Polsce miały miejsce dramatyczne wydarzenia. Jednak inaczej było w Ryswick, gdzie od połowy maja rozmowy pokojowe posunęły się bardzo nieznacznie. „Widzi Pan”, napisał Prior do sir Williama Trumbulla w Londynie, ,jak powolny jest tutaj postęp” ${ }^{49}$. Inni, wśród nich Richard Hill i William Blathwayt, powtarzali słowo „wolno", wspominając w swojej korespondencji o rozmowach w Ryswick ${ }^{50}$. Zarówno Prior, jak i Hill narzekali na „drobiazgi”, do których negocjatorzy

45 Taki sposób elekcji króla polskiego przypomina wybór kandydata na urząd prezydenta Stanów Zjednoczonych Ameryki Północnej podczas Konwencji Narodowej każdej z dwóch głównych partii politycznych, z identycznym naciskiem na jednomyślność.

${ }^{46}$ Historical Manuscripts Commission. Calendar, Vol. 3, s. 133.

47 „Gazette” 3306.

48 Historical Manuscripts Commission. Report, Vol. 2, s. 496.

49 Historical Manuscripts Commission. Calendar, Vol. 3, s. 119. W latach 1695-1697 sir William Trumbull zajmował stanowisko sekretarza stanu Departamentu Północnego, w tym samym czasie książę Shrewsbury pełnił funkcję sekretarza stanu Departamentu Południowego.

50 Historical Manuscripts Commission. Report, Vol. 2, s. 471; The Lexington Papers, ed. by H. Manners Sutton, London 1851, s. 283. William Blathwayt był sekretarzem stanu do spraw wojny, a kiedy Wilhelm III uczestniczył w działaniach wojennych, był pełniącym obowiązki sekretarza stanu. 
przywiązywali duże znaczenie ${ }^{51}$. Dobrym przykładem mało poważnego podejścia do obowiązków wśród dyplomatów była postawa angielskiego pełnomocnika sir Josepha Williamsona. Tak długo odkładał swój przyjazd do Ryswick, że nie zdążył na kilka początkowych sesji. Jego głównym zajęciem przed przyjazdem było uzyskanie całości wynagrodzenia związanego z pełnioną funkcją oraz troska o tytulaturę. Dokładał starań, aby wszystkie osoby, z którymi prowadził korespondencję, zwracały się do niego „milordzie i ekscelencjo - tytuł właściwy ambasadorom nadzwyczajnym" 52 .

Williamson przyznawał, że procedury, które stosowano, miały negatywny wpływ na tempo rozmów pokojowych ${ }^{53}$, z kolei Burnet próbował wyjaśnić, dlaczego tak się działo. Jak stwierdził, rozmowy polegały „na wymianie dokumentów i była to powolna metoda, która często ulegała dodatkowym opóźnieniom" ${ }^{34}$. Dopiero w drugim miesiącu negocjacji wszyscy uczestnicy zgodzili się „odłożyć nużący sposób komunikowania się na piśmie i zamiast tego omawiać sprawy" ${ }^{\prime 2}$. Ale nawet wtedy przedstawiciele cesarza unikali „indywidualnych rozmów z Francuzami” ${ }^{56}$. Sojusznicy cesarza z coraz większym zirytowaniem spoglądali na trwającą tygodniami bezczynność w Ryswick. Prior wzywał do przyjęcia „lepszej metody”, a Hill w gwałtowny sposób wyrażał opinię, że „trzeba zrobić coś wbrew zasadom”"57.

W poniedziałek 8 lipca rzeczywiście próbowano zrobić „coś wbrew zasadom”. Prawa ręka Wilhelma III, Hans William Bentinck, hrabia Portland, spotkał się z Ludwikiem Franciszkiem Boufflers, osobistym przedstawicielem Ludwika XIV. Panowie odbyli dwugodzinną rozmowę na świe-

51 Historical Manuscripts Commission. Report, Vol. 2, s. 469; The Lexington..., s. 264.

52 Letters illustrative of the Reign of William III from 1696 to 1708 addressed to the Duke of Shrewsbury by James Vernon, Esq. Secretary of State, ed. by G. P. R. James, Vol. 1, London 1841, s. 153, 270-271.

53 Historical Manuscripts Commission. Report, Vol. 2, s. 504 - „tracąc czas na oficjalnych spotkaniach i rozmowach".

54 G. Burnet, op. cit., Vol. 4, s. 357.

55 "Gazette” 3295.

56 Letters of William III and Louis XIV and of their Ministers, ed. by P. Grimblot, Vol. 1, London 1848, s. 96.

57 Historical Manuscripts Commission. Calendar, Vol. 3, s. 131; Historical Manuscripts Commission. Report, Vol. 2, s. 471. 
żym powietrzu. Ani w tym, ani w kolejnych spotkaniach nie uczestniczył nikt poza nimi. W przerwach między tymi spotkaniami Portland i Boufflers konsultowali się ze swoimi władcami. W rezultacie udało się przełamać impas i rozwiązać najważniejsze problemy. Nie podobało się to cesarzowi, ale jak zauważył Shrewsbury, Anglicy i Holendrzy płacili za wojnę, a ich sojusznicy powinni „pozwolić zdecydować im, kiedy najlepiej zakończyć wojnę"58.

Rozmowy Portlanda i Boufflersa zwiększyły nadzieje na szybkie podpisanie pokoju. W listach wysyłanych pod koniec lipca i na początku sierpnia Hill i Prior pisali z większym optymizmem niż poprzednio o perspektywie zakończenia wojny ${ }^{59}$. Jednak nie brali pod uwagę sytuacji w Katalonii, gdzie Francuzi zaciskali pętlę oblężenia wokół Barcelony. Armia hiszpańska, która mogła odblokować miasto, poniosła porażkę w niedzielę 14 lipca, a nieco ponad tydzień później Francuzi zdobyli zewnętrzne umocnienia i bastiony. W poniedziałek 5 sierpnia garnizon skapitulował i opuścił miasto $10 \mathrm{dni}$ później. Tak jak w przypadku garnizonu Ath, żołnierzom pozwolono wyjść przy biciu w bębny i ze sztandarami, jednak tym razem zostawiono im moździerze i armaty ${ }^{60}$. W tym samym czasie przyszły kolejne wiadomości o porażkach sprzymierzonych. Trzy miesiące wcześniej Francuzi zdobyli Cartagenę, hiszpański port nad Morzem Karaibskim. Eskadra okrętów dowodzona przez Jeana-Bernarda de Pointis niespodziewanie przepłynęła Atlantyk, unikając spotkania z marynarką angielską ${ }^{61}$.

Upadek Barcelony i sukcesy Francuzów na morzu boleśnie uderzyły w Wilhelma III. On także był optymistą po początkowym sukcesie rozmów między Portlandem a Boufflersem. Decyzją o bezpośrednich rozmowach z Ludwikiem XIV zdobył powszechne uznanie, a w piątek 2 sierpnia był gotów zakończyć działania wojenne, aby udać się na polowanie do swych holenderskich posiadłości. Prior zapisał:

58 Letters of William III, Vol. 1, s. 85.

59 Zob.: Historical Manuscripts Commission. Report, Vol. 2, s. 500.

${ }^{60}$ A. Boyer, op. cit., Vol. 3, s. 254-256; N. Luttrell, op. cit., Vol. 4, s. 266.

61 „Gazette” 3314. 
opuszczenie armii przez Jego Królewską Wysokość wskazuje tak wyraźnie na pokój, jak wcześniej jego obecność u boku armii wskazywała na wojnę ${ }^{62}$.

Jednak w ciągu kilku dni okazało się, że król zbyt szybko opuścił swój posterunek. „Sprawy przybrały bardzo niekorzystny obrót”, pisał pod koniec miesiąca do księcia Shrewsbury. „Godna pożałowania utrata Barcelony... oraz ucieczka Pointisa... mogą przeszkodzić w zawarciu pokoju, który, jak sądziłem, był już pewny" ${ }^{63}$. Podobne obawy żywił Richard Hill, który stwierdził, że Ludwik XIV może „stracić chęć” zawarcia pokoju ${ }^{64}$. Kilka lat później Boyer, podsumowując ówczesną sytuację, poszerzył perspektywę, zwracając uwagę na wydarzenia na drugim końcu Europy. Jak pisał,

według wszelkiego prawdopodobieństwa sukcesy we Flandrii i Katalonii pozwoliłyby Francuzom dyktować warunki pokoju..., gdyby nie to, że doznali zawodu w Polsce ${ }^{65}$.

Ludwik XIV mógł wykorzystać potęgę militarną Francji, aby wpłynąć na elekcję w Rzymie w 1691 roku i w Liege trzy lata później. Jednak w przypadku Polski nie było to takie łatwe. Także elektor saski we współpracy z cesarzem mógł wprowadzić wojsko do Polski, aby zakończyć sprawę. Francuzi mogli co najwyżej złożyć protest. Twierdzili, że podczas elekcji nie przestrzegano podstawowych zasad prawa oraz że elektor saski „nie został wybrany we właściwy sposób, to znaczy poprzez aklamację i powszechną zgodę”. Dwa tygodnie później dodali kolejny argument, twierdząc, że tylko arcybiskup gnieźnieński „ma prawo ogłosić kandydata królem, podpisać dokument potwierdzający jego elekcję oraz dokonać koronacji” ${ }^{66}$. Informacje te pojawiły się w „London Gazette” w sierpniu, a w kolejnych miesiącach wiadomości z Polski zajmowały więcej miejsca niż zazwyczaj.

\footnotetext{
${ }^{62}$ Historical Manuscripts Commission. Calendar, Vol. 3, s. 144.

63 Letters of William III, Vol. 1, s. 61.

${ }^{64}$ Historical Manuscripts Commission. Report, Vol. 2, s. 530.

65 A. Boyer, op. cit., Vol. 3, s. 256.

66 „Gazette” 3309, 3313.
} 
Czytelnicy w Anglii mogli śledzić, choć opisywane tylko z jednej perspektywy, wydarzenia na drugim krańcu kontynentu. Mogli między innymi przeczytać o wspaniałej wyprawie elektora saskiego na koronację do Krakowa. W lipcu elektor był na Śląsku, najpierw we Wrocławiu, następnie w Tarnowskich Górach nad granicą z Polską, gdzie przyjął „wielkie poselstwo” złożone z wysokich dostojników, którzy zaprosili go do wkroczenia do jego nowego królestwa ${ }^{67}$. Granicę przekroczył pod koniec miesiąca (,z 8 bądź 10 tysiącami ludzi”), a w czwartek 8 sierpnia rozłożył się na zamku w Krakowie. Jego oficjalny wjazd do miasta odbył się pięć tygodni później ${ }^{68}$.

Zwolennicy księcia Conti ciągle jednak nie zostali pokonani. Co prawda Conti nie wyruszył jeszcze do Polski, ale mógł liczyć na poparcie ze strony prymasa, a dopóki trwało bezkrólewie, prymas był jednym legalnym źródłem władzy w królestwie. W „Gazette” pojawiły się informacje, że prymas może wezwać do nowej elekcji i że w tym celu zwoła sejm. Wyrażano obawy, że najprawdopodobniej taka decyzja doprowadzi do wojny domowej ${ }^{69}$. Elektor saski dysponował własną armią, ale był tylko kandydatem do tronu i musiał znaleźć sposób na jego legalne objęcie. Najbardziej oczywistym rozwiązaniem była koronacja, nawet jeśli arcybiskup gnieźnieński odmówiłby przewodniczenia uroczystości. W celu zminimalizowania jego nieobecność dołożono wszelkich starań, aby uroczystość wypadła jak najbardziej okazale. Inne angielskie gazety ${ }^{70}$ wspominały o transportach złota, srebra i diamentów z Drezna do Krakowa w oczekiwaniu koronacji, która odbyła się w niedzielę 15 września. W uroczystościach wzięło udział „mnóstwo szlachty”, a nowy władca został ukoronowany przez biskupa Stanisława Dąmbskiego, który odegrał kluczową rolę podczas elekcji ${ }^{71}$.

Zanim wiadomości o wydarzeniach w Krakowie dotarły do negocjatorów w Ryswick, ci zdążyli już zakończyć swoją pracę. W piątek, 20 września, Anglicy, Holendrzy i Hiszpanie podpisali traktaty z Francuzami. Tylko cesarz opóźniał ten akt, ale przed końcem października także jego

67 „Gazette” 3311; N. Luttrell, op. cit., Vol. 4, s. 259.

68 „Gazette” 3312, 3319.

69 „Gazette” 3309, 3321; N. Luttrell, op. cit., Vol. 4, s. 256, 272.

${ }^{70}$ N. Luttrell, op. cit., Vol. 4, s. 252.

71 „Gazette” 3326. 
przedstawiciele złożyli podpisy. Sytuacja w Polsce nie miała już wpływu na wydarzenia w Ryswick, ale jeszcze kilka tygodni wcześniej wyglądało to inaczej. Francuzi przedstawili ostateczny „projekt pokoju” w sobotę 20 lipca, zaznaczając, że sojusznicy muszą go zaakceptować bądź odrzucić do ostatniego dnia sierpnia. Sojusznicy nie dotrzymali terminu, w związku z czym następnego dnia po tej dacie Francuzi ogłosili, że traktat końcowy będzie zawierał cięższe warunki. W międzyczasie upadła Barcelona, co dodatkowo wzmocniło pozycję Ludwika XIV. Nie chciał zatrzymać w swoim ręku Barcelony czy Ath, ale w zamian za nie mógł pozostawić niektóre wcześniejsze zdobycze. W 1681 roku, opierając się na wątpliwym tytule prawnym, Ludwik XIV zajął Strasburg, a żaden traktat międzynarodowy nie potwierdzał tej zdobyczy. Wśród nowych warunków pokoju przedstawionych w niedzielę 1 września znajdowało się żądanie, aby sojusznicy uznali i potwierdzili francuskie prawo do Strasburga. Przez trzy tygodnie zawarcie pokoju wisiało na włosku i nie ma wątpliwości, że gdyby Ludwik otrzymał pomyślniejsze wiadomości z Polski, kolejny raz zaostrzyłby swoje stanowisko, co z kolei skłoniłoby sojuszników do ich odrzucenia. W dzienniku Johna Evelyna znalazł się następujący wpis:

Niepewne wiadomości na temat pokoju, który wydawał się tak bliski zawarcia; król francuski jest niesłowny i w oczywisty sposób opóźnia wydanie ostatecznej decyzji, czekając, jak sądzę, na pomyślne wiadomości z Polski ${ }^{72}$.

Informacje, że elektor saski wkroczył na czele armii do Krakowa, w widoczny sposób wpłynęły na stanowisko Ludwika XIV i otworzyły drogę do zawarcia pokoju w zachodniej części Europy.

Zdaniem Burneta pokój w Ryswick był wielkim osiągnięciem Wilhelma III:

Dzięki temu traktatowi król zrealizował swój plan powstrzymania ekspansji militarnej Francji, plan, który starał się osiągnąć od pojawienia się na arenie międzynarodowej w $1672 \mathrm{roku}^{73}$.

72 The Diary..., s. 1016.

73 G. Burnet, op. cit., Vol. 4, s. 359. 
Jako książę orański Wilhelm zabiegał o bezpieczeństwo Zjednoczonych Prowincji, a jako król Anglii - o uznanie swego tytułu monarszego i wycofanie przez Francję poparcia dla Jakuba II. Dzięki podpisanemu pokojowi udało się choć częściowo przybliżyć realizację tych planów. Jednak poddani Wilhelma III wyrażali zadowolenie głównie z samego zakończenia konfliktu. Kolejny raz podsumował to John Evelyn, pisząc krótko po tym, gdy w Anglii pojawiły się szczegółowe informacje: „Mamy wreszcie gorąco oczekiwane wiadomości o pokoju z Francją”. W dalszej części dodał jednak kilka mniej oczekiwanych informacji, kończąc ten fragment słowami: „książę Conti wyrusza do Polski...”74 .

Conti wypłynął z Dunkierki pod koniec pierwszego tygodnia września. Zabrał ze sobą nieco wojska, ale ekspedycja nie była duża: cztery bądź pięć „małych fregat”, które tworzyły eskadrę pod dowództwem Jeana Barta ${ }^{75}$. Siły te przybyły do Gdańska w środę 25 września, ale miejscowe władze nie wydały żołnierzom zgody na zejście na ląd. Jeszcze bardziej dotkliwy dla Contiego był fakt, że zaledwie cztery dni później miasto opowiedziało się po stronie jego rywala, który w tym momencie był już koronowany jako August II ${ }^{76}$. W tym samym czasie prymas uznał, że najmądrzej będzie wyjechać z Warszawy, ale zwolennicy Contiego zrekompensowali to sobie, zajmując Malbork, około 20 mil od wybrzeża Bałtyku ${ }^{77}$. Władze Gdańska nadal psuły szyki księciu i w rezultacie nie mógł on przetransportować ani żołnierzy, ani uzbrojenia z okrętów do Malborka ${ }^{78}$. Czytelnicy w Anglii nadal mogli śledzić te i następne wydarzenia w Polsce, choć informacje były krótsze i zamieszczano je rzadziej niż latem.

Książę Conti pozostawał na okrętach przez cały październik. Często schodził na ląd, aby przyjąć polskich gości w pobliskim klasztorze w Oli-

74 The Diary..., s. 1016.

75 Ambasador elektora saskiego w Zjednoczonych Prowincjach zwrócił się do Wilhelma III z prośbą o zablokowanie Dunkierki, „aby uniemożliwić Bartowi wypłynięcie z portu, a to ze względu na pogłoski, że Bart ma przetransportować księcia Conti na północ”. „Gazette” 3320, 3321; Historical Manuscripts Commission. Calendar, Vol. 3, s. 138; The Lexington..., s. 305.

76 „Gazette” 3327, 3329, 3331.

77 „Gazette” 3327, 3331; N. Luttrell, op. cit., Vol. 4, s. 290.

78 „Gazette” 3329. 
wie, jednak nie czuł się na tyle pewnie, aby spędzić noc z dala od okrętów ${ }^{79}$. Czas mijał, pogoda się pogarszała, utrudniając okrętom pozostawanie przy brzegu $^{80}$. Contiemu brakowało zarówno twierdzy, jak i portu. Książę nie mógł zapewnić schronienia swym żołnierzom ani na lądzie, ani na morzu. Jego powrót do Francji był kwestią oczywistą, zanim jeszcze żołnierze saksońscy podeszli pod Oliwę w piątek 8 listopada. W walkach zginęło bądź zostało pojmanych wielu zwolenników Contiego. Stracili też wiele cennych przedmiotów, między innymi „wspaniałą karetę” należącą do ambasadora Melchiora de Polignac, „który sam z trudnością zdołał uciec” ${ }^{\text {. }}$. Następnego dnia Conti i Bart odpłynęli do Francji ${ }^{82}$.

Ludwik XIV był rozwścieczony haniebnym zakończeniem wyprawy Contiego. Kazał zająć wszystkie statki należące do kupców gdańskich i zagroził wysłaniem silniejszej eskadry, aby zbombardować miasto ${ }^{83}$. Gniew odzwierciedlał frustrację $\varepsilon^{84}$ wywołaną przez fakt, że międzynarodowa koalicja utworzona i podtrzymywana przez Wilhelma III zdołała pokrzyżować jego plany. Podczas wojny dziewięcioletniej jednym z celów króla francuskiego było rozbicie koalicji poprzez wyłuskiwanie z jej szeregów jednego państwa po drugim. Dzięki połączeniu gróźb i obietnic zdołał zawrzeć separatystyczny pokój z Sabaudią w 1696 roku, a zdobycie Barcelony przyczyniło się do wyeliminowania z wojny Hiszpanii. Miał nadzieję, że dzięki osadzeniu Contiego na tronie polskim zdoła także osiągnąć porozumienie z cesarzem.

Paradoksalnie, sam Conti był daleki od entuzjazmu, jeśli chodzi o całą wyprawę. Według „Madame” (szwagierki Ludwika XIV, Elżbiety Charlotty, księżnej Orleanu) książę wypowiadał się zdecydowanie przeciwko wysłaniu

79 Według jednej z relacji Conti znalazł się w niebezpieczeństwie ze względu na pogróżki „tłumu”. „Gazette” 3335, 3337; N. Luttrell, op. cit., Vol. 4, s. 287.

80 „Gazette” 3329, 3339.

81 "Gazette" 3340.

82 „Gazette” 3342; The Lexington..., s. 319, 321. W drodze powrotnej Conti spędził dwa dni w Kopenhadze, ale wydaje się, że ostatnie doświadczenia wpłynęły nań tak negatywnie, że nie przedstawił się na dworze duńskim.

${ }^{83}$ N. Luttrell, op. cit., Vol. 4, s. 293, 304, 307.

${ }^{84}$ Ówcześni mówili również o jego „upokorzeniu”. Historical Manuscripts Commission. Report, Vol. 2, s. 486; A. Boyer, op. cit., Vol. 3, s. 258. 
go do Polski ,jak zbłąkanego włóczęgi” z niedostatecznymi siłami i niepewnym przyjęciem ${ }^{85}$. Jednak Ludwik XIV nalegał, aby książę wyruszył. Król, który przyznawał, że nie lubi młodszego kuzyna, zazdrościł Contiemu popularności i wpływu na delfina; właściwie był zadowolony z możliwości wysłania go do odległej części Europy ${ }^{86}$. Nie powinien więc zaskakiwać fakt, że Conti działał w tak niezdecydowany sposób po przybyciu w pobliże Gdańska. Stworzywszy pozory, jak żądał tego Ludwik XIV, wycofał się natychmiast po napotkaniu poważniejszego oporu. Wilhelm III obawiał się, że po zawarciu pokoju na zachodzie Europy, dojdzie do „wielkich sporów” na wschodzie, „ponieważ Francja będzie mogła wówczas pomóc księciu Conti" ${ }^{87}$. Jednak Ludwik XIV stracił zainteresowanie Polską, zwracając uwagę na większą zdobycz w postaci sukcesji hiszpańskiej.

Sukcesją hiszpańską, która miała stać się kwestią otwartą po śmierci ostatniego z Habsburgów hiszpańskich, był zainteresowany także cesarz Leopold, pochodzący $\mathrm{z}$ innej gałęzi tego samego rodu. $\mathrm{Z}$ tego powodu chciał kontynuować wojnę dziewięcioletnią, aby jego sojusznicy, Anglia i Zjednoczone Prowincje, mogli mu przyjść z pomocą, gdy będzie ich potrzebował. Jak stwierdził Richard Hill, cesarz z niepokojem obserwował zdrowie swojego krewniaka „i byłby szczęśliwy, gdyby cały świat toczył wojnę w momencie jego śmierci”"88. Wyjaśnia to, dlaczego przedstawiciele cesarza w Ryswick robili wszystko co w ich mocy, aby opóźnić rozmowy pokojowe $^{89}$, odmawiając bezpośrednich spotkań z dyplomatami francu-

85 The Letters of Madame. The Correspondence of Elizabeth-Charlotte of Bavaria, Princess Palatine, duchess of Orleans, called "Madame" at the court of the king Louis XIV, ed. by G. Scott Stevenson, Vol. 1, London 1924, s. 153-154.

${ }^{86}$ Zdaniem Henry Sydneya, earla Romney, kiedy Conti wypłynął z Dunkierki, Ludwik XIV „był zadowolony, że się go pozbył”. Correspondentie van Willem III en van Hans Willem Bentinck, uitgegeven door N. Japikse, Vol. 2, Hague 1928, s. 78; The Lexington, s. 121.

$87 \mathrm{~W}$ innym ze swoich listów Wilhelm III zapisał, że „Francja wypowiedziała wojnę Gdańskowi”. Letters of William III, Vol. 1, s. 101-102, 133.

88 Historical Manuscripts Commission. Report, Vol. 2, s. 447.

${ }^{89}$ Pełnomocnik cesarski, Johann Friedrich von Seilern, „zanudzał delegatów kwestiami prawnymi dotyczącymi Strasburga” i „wyciągał każdy precedens, każdy związek dynastyczny i każdy traktat”. J. P. Spielman, Leopold I of Austria, New Brunswick 1977, s. 158. W końcu jednak Austriacy musieli zaakceptować traktat sankcjonujący zajęcie Strasburga przez Francję. 
skimi, i nie dotrzymali przedstawionego przez Francuzów terminu zawarcia pokoju.

Istniał jeszcze jeden powód, dla którego Leopold chciał, aby wojna na zachodzie Europy trwała. W 1697 roku prowadził dwie odrębne wojny: jedną, korzystając z subsydiów angielskich i holenderskich, przeciwko Francji i drugą na terenie Węgier przeciwko Turkom. Matthew Prior widział konsekwencje takiego stanu rzeczy jeszcze przed rozpoczęciem negocjacji w Ryswick:

Turcy... nie skłonią ucha ku pokojowi, a cesarz będzie raczej wolał prowadzić dwie wojny, przy czym jedna z nich nic go nie kosztuje, niż prowadzić jedną wojnę, podczas której cały świat będzie widział jego słabość, bez sojuszników ${ }^{90}$.

Sobieski był sojusznikiem w wojnie na wschodzie Europy, ale gdyby książę Conti został królem Polski, cesarz nie mógłby liczyć na pomoc z jego strony. Częścią polityki Ludwika XIV było zachęcanie Turcji do wojen z Austrią po to, aby uniemożliwić cesarzowi interwencję przy okazji zmieniania przez Francję granic Niemiec, jak miało to miejsce w przypadku Strasburga. Gdyby Conti został królem Polski, byłby stałym zagrożeniem na flance Leopolda, zmuszając go, aby stał się, jak to ujął Boyer, „bardziej podatny na sugestie" podczas rozmów pokojowych w Ryswick ${ }^{91}$. Przeciwna sytuacja, czyli porażka Contiego i sukces elektora saskiego, okazały się, jak zauważył Matthew Prior, przeszkodą podczas negocjacji: „bieg wydarzeń ma wpływ na to, że Cesarscy w mniejszym stopniu skłaniają się ku pokojowi”92.

To, że sytuacja w Polsce wyjaśniła się dokładnie w tym samym czasie, kiedy został zawarty pokój w Ryswick, miało duże znaczenie. Okres między początkiem sejmu w Warszawie (15 maja) a koronacją nowego króla w Krakowie (15 września) zbiegł się ze wzmożoną aktywnością dyplomatów w Zjednoczonych Prowincjach, od przedstawienia listów uwierzytelniających do podpisania traktatu pokojowego ( 9 maja - 20 września). Z punktu widzenia dyplomatów kluczowa okazała się druga połowa sierpnia, kiedy

\footnotetext{
90 Historical Manuscripts Commission. Calendar, Vol. 3, s. 106.

${ }^{91}$ A. Boyer, op. cit., Vol. 3, s. 253.

92 Historical Manuscripts Commission. Calendar, Vol. 3, s. 134.
} 
wiadomo było, że Francuzi zdobyli Barcelonę, ale nie było jeszcze jasne, który z kandydatów obejmie tron, gdyby doszło do wojny domowej. Kilka tygodni wcześniej sir Joseph Williamson umieścił oblężenie Barcelony i elekcję w Polsce „wśród trzech czy czterech wydarzeń, z którymi Francja wiąże duże nadzieje"93. Podobną opinię na temat francuskich "planów” i „projektów” wyraził Shrewsbury ${ }^{94}$. Francuzi wyznaczyli termin przyjęcia ich propozycji pokojowych, ale w drugiej połowie sierpnia wydawało się, że nie dbają o to, czy ich przeciwnicy przekroczą ten czas. Dla Wilhelma III, który bał się, że szansa na zawarcie pokoju może się wyśliznąć, był to poważny powód do zmartwień. Uważał przekroczenie terminu za wielkie nieszczęście i zwierzył się Portlandowi, że nie wie, co robićn 95 . Dla Wilhelma III związek między rozmowami pokojowymi a wydarzeniami w Polsce miał bezpośredni i oczywisty charakter. Czy pozycja Ludwika XIV ulegnie wzmocnieniu czy osłabieniu ze względu na sytuację w Polsce i czy skłoni go to do przyjęcia rozsądnych warunków pokoju, czy też nie? W takiej sytuacji Wilhelm III z wielką ulgą przyjął wiadomości o końcowym zwycięstwie elektora saskiego. Historycy często przedstawiają elekcję 1697 roku wyłącznie jako „sprawę północy” ${ }^{\text {, }}$, ale dyplomaci obradujący w Ryswick uważali ją za sprawę o kapitalnym znaczeniu dla negocjacji pokojowych i wielokrotnie powtarzali to w korespondencji. Elektor Saksonii, popierany przez wrogów króla Francji, zadał decydujący cios w Polsce i na tym tle nawet utrata Barcelony była tylko chwilowym niepowodzeniem. W rywalizacji między Wilhelmem III i Ludwikiem XIV o trony elekcyjne ten pierwszy zdobył kolejne pole na europejskiej szachownicy. Sir Joseph Williamson, jeden z głównych negocjatorów w Ryswick, odetchnął z wyraźną ulgą na wiadomość o tym, jak zwolennicy księcia Conti zostali wymanewrowani. Zrozumiał w lot, że dzięki wiadomościom z Warszawy jego zadanie stało

93 Private and Original Correspondence of Charles Talbot, Duke of Shrewsbury, ed. by W. Coxe, London 1821, s. 342.

94 Historical Manuscripts Commission. Report, Vol. 2, s. 497; Letters of William III, Vol. 1, s. 70.

95 Letters of William III, Vol. 1, s. 103.

96 Wyrażenie to było powszechnie stosowane w ówczesnej korespondencji, na przykład przez Charlesa Montagu, earla Manchesteru, zob.: Historical Manuscripts Commission. Calendar, Vol. 3, s. 402, 404. 
się dużo łatwiejsze, a wynik elekcji w Polsce określił z radością jako „bardzo szczęśliwy obrót spraw"97.

ttumaczenie: Pawet Hanczewski

\section{„A Very Lucky Turn”. Peace-making at Ryswick and King-making in Poland}

(SUMMARY)

The death of John Sobieski in June 1696, and the process of choosing his successor twelve months later, were reported at length in newsletters in England, and were discussed in detail by English diplomats and politicians. There were numerous elective thrones in seventeenth-century Europe, and vacancies resulted in contests in which the major powers of the continent frequently became involved. The election of a new King of Poland in the summer of 1697 coincided with the peace negotiations at Ryswick which eventually brought to an end the current European war between Louis XIV of France and his opponents. French expectations of victory in the contest at Warsaw diminished their commitment to these negotiations, but a treaty at Ryswick became possible in September once it was clear that the French candidate had failed to establish himself on the Polish throne.

Richard Price emerytowany kierownik katedry historii w Boston Grammar School, wieloletni nauczyciel historii m.in. w Lycée des Eaux Claires w Grenoble i European School w Karlsruhe

${ }^{97}$ Letters illustrative..., Vol. 1, s. 306. 